\title{
Characterization of Triatoma guasayana Biotopes in a Hardwood Forest of Santiago del Estero, Argentina
}

\author{
Darío Vezzani, Nicolás J Schweigmann, Silvia M Pietrokovsky, \\ Cristina Wisnivesky-Colli ${ }^{+}$
}

Unidad de Ecología de Reservorios y Vectores de Parásitos, Departamento de Ciencias Biológicas, Facultad de Ciencias Exactas y Naturales, Universidad de Buenos Aires, Ciudad Universitaria, Pabellón II, $4^{\circ}$ p, 1428

Buenos Aires, Argentina

Triatoma guasayana is a silvatic triatomine species distributed in Argentina, Bolivia and Paraguay. The study was performed in a secondary forest of Santiago del Estero, Argentina. The abundance of T. guasayana was evaluated by census in the following wild biotopes: quimiles (Opuntia quimilo), chaguares (dry bromeliads), logs and underground burrows. Ten biotopes of each type were dismantled in winter (August) and another 40 in summer (January); all fauna was recorded. The biotopes most infested by T. guasayana were quimiles (65\%), followed by chaguares (55\%), and logs (25\%). Quimiles and chaguares were infested in both seasons, whereas logs were positive only in summer and burrows were never infested. Infestation and abundance were higher in summer than in winter. The biotope structure is a key factor for T. guasayana colonization. The larger number of refuges, the constant presence of blood sources and suitable inner microclimatic conditions offered by quimiles may favour the persistence of T. guasayana colonies. The richness of invertebrate fauna per type of biotope was ranked in the same order as that of T. guasayana, suggesting similar microhabitat requirements for all studied arthropods.

Key words: Triatoma guasayana - silvatic triatomines - microhabitats - biotopes - census - Argentina

Triatoma guasayana Wygodzinsky \& Abalos is a silvatic triatomine species (Hemiptera: Reduviidae) distributed in Central and Northern Argentina, Bolivia, and Paraguay (Lent \& Wygodzinsky 1979, Noireau et al. 1999). In the hardwood forest of Santiago del Estero, Argentina, T. guasayana has been found in dry cactacea, bromeliads, and logs, which are also used as temporary shelters by opossums (Didelphis albiventris), the main wild reservoir host of Trypanosoma cruzi (Schweigmann et al. 1999).

Those biotopes, considered as wild parasite transmission foci, showed very low $T$. guasayana densities (Wisnivesky-Colli et al. 1997), probably due to the methods used to capture triatomines. Conventional sampling methods (man/hour method, inspection using dislodging substances) do not ensure an accurate estimation of the population inhabiting a biotope. The census, an ex-

\footnotetext{
This research was supported by the Secretaría de Ciencia y Técnica, Universidad de Buenos Aires (PID EX 184). ${ }^{+}$Corresponding author. Fax: +54-11-48545412 E-mail: criswi@biolo.bg.fcen.uba.ar or tato@ba.net Received 29 May 2000 Accepted 14 February 2001
}

tremely demanding method, was unnecessary in previous studies on biotope occurrence and spatial distribution of T. guasayana. However, the fact that silvatic transmission modeling needs more precise values of $T$. guasayana abundance, prompted us to carry on a census in every biotope.

Since Schweigmann (1994) showed that opossums periodically shelter in underground burrows (caves), we included in our study these biotopes which had never been inspected for triatomines before.

Although available literature provides general information on triatomine habitat (Rabinovich 1985), there are no specific descriptions of inner biotope structures with the exception of palms in Venezuela (Pifano 1973, Rossell Reyes 1984). In order to characterize the microhabitat of $T$. guasayana, we describe the inner structure of its biotopes and the coexisting fauna.

\section{MATERIALS AND METHODS}

Study area - The study was conducted in a secondary forest showing a variable degree of human intervention. It was located in the Department of Moreno, Province of Santiago del Estero, Argentina, near the settlement of Trinidad $\left(27^{\circ} 12^{\prime} 30^{\prime \prime} \mathrm{S}\right.$, $\left.63^{\circ} 02^{\prime} 30^{\prime \prime} \mathrm{W}\right)$. Biogeographically, the area belongs to the dry western district of the Chaco Region (Cabrera \& Willink 1973) with a semiarid climate corresponding to the BS type of Köppen's classi- 
fication (Pettersen 1976). There is marked seasonality, with a dry autumn/winter season (May through October) and a rainy period throughout the rest of the year. Mean annual rainfall is 740 $\mathrm{mm}$ and relative humidity ranges between 55 and $68 \%$ (Anonymous 1982). The environmental features of the area have been described in a previous work performed between 1989 and 1992 (Wisnivesky-Colli et al. 1997). In 1993, an intense deforestation resulted in scattered patches of forest.

This study was carried out from July 27 th to August 30th 1995 (winter/cold season) and from January 20th to February 21st 1996 (summer/warm season). They represent the extreme points of environmental conditions and triatomine population abundance. According to The National Meteorological Office, the mean minimum and maximum temperatures were $6^{\circ} \mathrm{C}$ and $24.2^{\circ} \mathrm{C}$ in winter and $19.3^{\circ} \mathrm{C}$ and $33.1^{\circ} \mathrm{C}$ in summer.

Sampling - The biotopes selected for the present study were dry and fallen Opuntia quimilo commonly known as quimiles, underground burrows (caves), decomposed logs of fallen trees, and dry bromeliads (Bromelia sp.) locally known as chaguares. Biotopes were completely dismantled and examined to collect all $T$. guasayana individuals and other arthropods larger than $1 \mathrm{~mm}$ (except for colonial species). The presence and identification of vertebrates were also recorded in each biotope.

Ten biotopes of each type were sampled in the cold season and 10 in the warm one, giving a total of 80 biotopes. All these biotopes were located in a natural environment, further than $150 \mathrm{~m}$ from the nearest house. Field work was always accomplished by the same person.

Quimiles and dry logs were cut into pieces of approximately $1 \mathrm{~m}$, which were completely dissected on a white canvas to facilitate capture of small instars.

Underground burrows with an opening of 10$30 \mathrm{~cm}$ in diameter were dug to their base tumbling down walls, and all the removed soil was subsequently sieved through two wire meshes with pores of $1 \mathrm{~cm}$ and $1 \mathrm{~mm}$, respectively. Chaguares were first examined in situ and after being rooted up with a shovel, they were examined on a white canvas. Leaves were torn apart, and the rosette-like leaf base was cut in half.

All the triatomines were shipped alive to the laboratory for species determination (Abalos \& Wygodzinsky 1951, Gorla et al. 1993) and instar and sex identification. The remaining arthropods, fixed in ethanol $70 \%$ in the field, were determined using appropriate keys.
Data analysis - Comparison between the proportions of biotopes infested by T. guasayana were performed by the $\chi^{2}$ test. The relationships between abundance of triatomines and different biotopes or seasons were analyzed by the Mann-Whitney test (Fleiss 1981). We set the significance level at $\mathrm{p}=$ 0.05 for both tests.

For other arthropods, we calculated richness (number of species) and Shannon's diversity index (richness related to the abundance for each species) for each biotope and each season (Magurran 1991). We tested for significant differences between diversities using the "t" test of Hutcheson (1970).

\section{RESULTS}

Biotope infestation - The biotopes most infested by $T$. guasayana were the quimiles (65\%), followed by chaguares $(55 \%)$ and $\operatorname{logs}(25 \%)$. Burrows were negative in both sampling seasons. In the cold season, $20 \%(6 / 30)$ of the biotopes were positive, whereas in the warm season, infestation was detected in 77\% (23/30) of the examined biotopes $\left(\chi^{2}=13.84, \mathrm{p}<0.05\right)$. Overall abundance was also higher in summer than in winter $(\mathrm{U}=189.5$, $\mathrm{p}<0.05$ ), even though the maximum observed number of triatomine per biotope was 14 individuals for both seasons, corresponding to one quimil in August and one chaguar in February.

While quimiles and chaguares were found infested in both seasons, logs were positive only in summer (Table I). In August, the chaguares and quimiles showed no significant differences either in the infestation rate or in the number of triatomines. In the warm season, differences were significant only between chaguares and logs, both in infestation rate $\left(\chi^{2}=4.267, \mathrm{p}<0.05\right)$ and in number of triatomines $(\mathrm{U}=13.5, \mathrm{p}<0.05)$.

When each type of biotope was compared between seasons, the infestation rate and abundance in chaguares were higher in summer than in win$\operatorname{ter}\left(\chi^{2}=12.93\right.$ and $U=3.515$ respectively, $\left.\mathrm{p}<0.05\right)$, whereas no differences were recorded for quimiles.

Concerning the composition of the population, adults were only found in the cold season (Fig.1) and first stage nymphs (N1) appeared only in the warm season (Fig. 2). Although second stage nymphs (N2) were more abundant in the summer, they were also collected in winter. The composition per biotope of the $T$. guasayana population in the warm season revealed the presence of all nymphal stages only in the chaguares (Fig. 2).

Biotope structure - Operational procedures carried out in each biotope took approximately $4 \mathrm{~h}$, except for chaguares which were dissected in $1 \mathrm{~h}$.

Quimiles (Fig. 3) are 1-4 m long cactacea having a cylindrical stem (the main part of the plant 
TABLE I

Proportion of positive biotopes, total number of individuals, median, standard deviation (SD) per season. July 27th-August 30th, 1995 (cold season) and January 20th-February 21st, 1996 (warm season), Department of Moreno, Province of Santiago del Estero, Argentina

\begin{tabular}{ccccc}
\hline Season & & Quimiles & Chaguares & Logs \\
\hline \multirow{4}{*}{ Cold } & Infestation rate & $5 / 10$ & $1 / 10$ & $0 / 10$ \\
& abundance & 36 & 2 & 0 \\
& $\mathrm{X}$ & 3.6 & 0.2 & 0 \\
& $\mathrm{SD}$ & 4.79 & 0.63 & - \\
& Infestation rate & $8 / 10$ & $10 / 10$ & $5 / 10$ \\
\multirow{4}{*}{ Warm } & abundance & 27 & 54 & 10 \\
& $\mathrm{X}$ & 2.7 & 5.4 & 1 \\
& $\mathrm{SD}$ & 2.45 & 4.55 & 1.56 \\
\hline
\end{tabular}

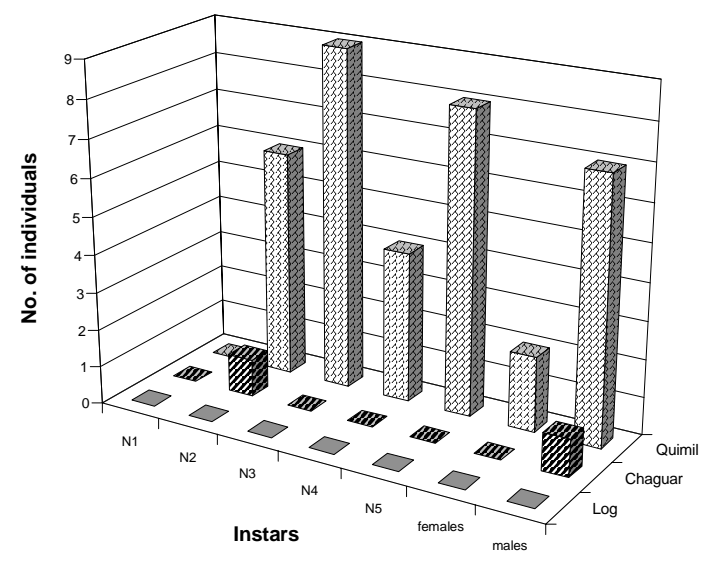

Fig. 1: composition of Triatoma guasayana population per biotope, July 27th to August 30th, 1995, Department of Moreno, Province of Santiago del Estero, Argentina

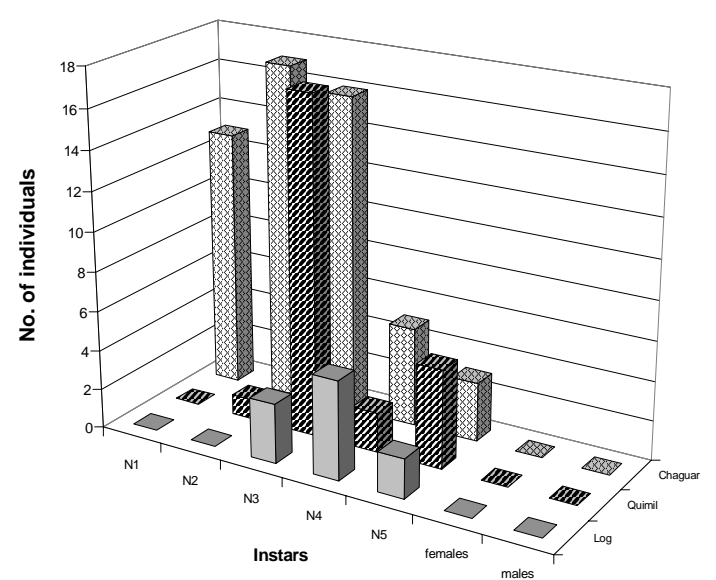

Fig. 2: composition of Triatoma guasayana population per biotope, January 20th to February 21st, 1996, Department of Moreno, Province of Santiago del Estero, Argentina body) that branches repeatedly. The stem has a thick cuticle that is partially detached and its bulk is composed of a mucilaginous ground tissue (absent when the plant is dry) in which a cylindrical network of vascular bundles is embedded. In patches of dead tissue, triatomines were found within the countless spaces provided by this network, as well as beneath the cuticle.

Chaguares (Figs 4, 5) are stemless plants with a circular cluster of stiff leaves, 1-1.5 m long, provided with strong marginal prickles. Bromeliads lack an inner fibrous structure, but axilar spaces between the leaves and the base supplied numerous shelters for triatomines.

Logs (Fig. 6) show different structure patterns according to their putrefaction grade, finally rendering a hollow trunk. Triatomines usually sheltered inside deep fissures of the hardwood and underneath the partially detached bark.

Caves are surrounded by bare soil. The opening connects with a main tunnel that branches in different directions. In the bottom of the tunnels, vertebrate nests made of plant debris were frequently found. Although no triatomine was found in the burrows, the nest might represent the only hiding place for triatomines, since the internal surface of the caves is smooth.

Associated fauna - A total of 2,837 specimens of the phylum Arthropoda belonging to 202 morpho-species were collected. The most abundant was a species of Blattodea (434 individuals) and one of Coleoptera (316 individuals). T. guasayana was the third most abundant species. A high percentage (25$30 \%$ ) of the associated arthropods corresponds to taxa that are considered as insect predators.

Richness of arthropods and statistical comparisons of Shannon's diversity indexes are summarized in Table II. Quimiles showed the largest number of species in both seasons; the diversity was higher in winter than in summer for all biotopes 


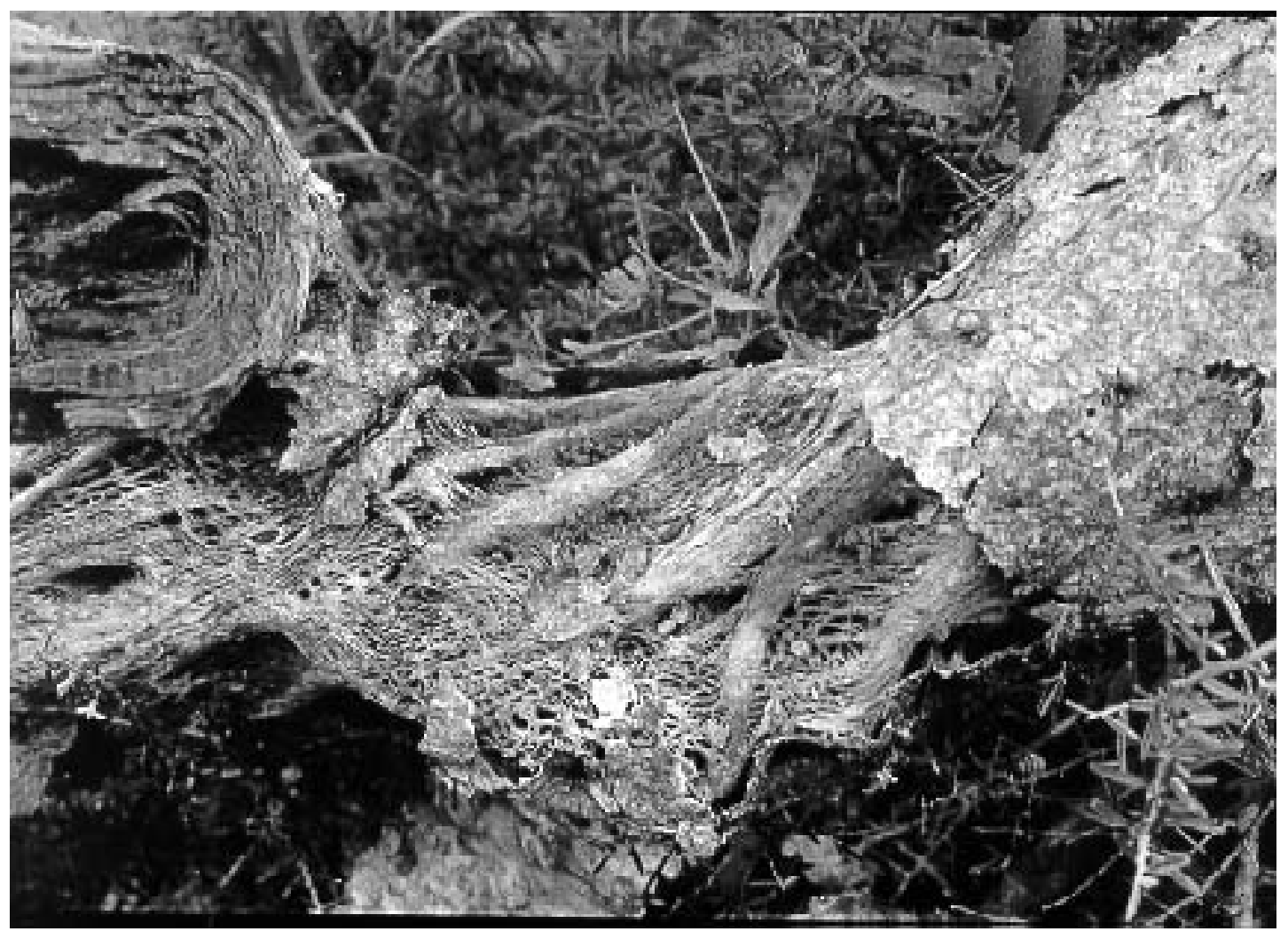

Fig. 3: Opuntia quimilo, quimil

except for burrows. In the cold season, diversity indexes were ranked as follows: quimiles> chaguares $>\log$ and burrows. In the warm season the diversity of quimiles, chaguares and burrows was similar and logs had the lowest index.

\section{TABLE II}

Richness and Diversity Indexes of arthropodian fauna, July 27th-August 30th, 1995 (cold season) and January 20th-February 21st, 1996 (warm season), Department of Moreno, Province of Santiago del Estero, Argentina

\begin{tabular}{llcc}
\hline Season & Richness & $\begin{array}{r}\text { Diversity H' } \\
\text { (Shannon) }\end{array}$ \\
\hline \multirow{2}{*}{ Cold } & Quimiles & 108 & $3.44 \mathrm{a}$ \\
& Chaguares & 44 & $3.05 \mathrm{~b}$ \\
& Logs & 25 & $2.75 \mathrm{c}$ \\
Burrows & 47 & $2.70 \mathrm{c}$ \\
Warm & Quimiles & 65 & $2.84 \mathrm{a}$, \\
& Lhaguares & 32 & $2.61 \mathrm{a}$ \\
& Burrows & 43 & $2.03 \mathrm{~b}$ \\
\hline
\end{tabular}

Shannon's indexes within files for each season are significantly different when followed by different letters (t test, $\mathrm{p}<0.05$ ).
Biotopes selected by $T$. guasayana were ranked in the same order as those of the invertebrate fauna.

During the inspection of the 80 biotopes, few vertebrates were recorded: 16 reptiles (12 small lizards, 2 boas and 2 other snakes), 2 opossums (Didelphidae) and 1 toad. Most animals were found in quimiles and caves. Domestic goats and pigs were frequently found resting near clusters of chaguares (chaguarales) during the warm season.

\section{DISCUSSION}

This is the first study of $T$. guasayana based on a census in its wild microhabitats in Argentina. Our results confirm previous observations in the same locality indicating that $T$. guasayana more frequently colonizes quimiles and chaguares than logs (Wisnivesky-Colli et al. 1997). However, in the present study the mean number of triatomines recorded per biotope and the infestation rate were higher than those recorded previously. This may be due to the exhaustive dissection procedure performed in the current survey allowing the capture of all triatomines (census) and the crowding of triatomines in those suitable biotopes left after deforestation. 


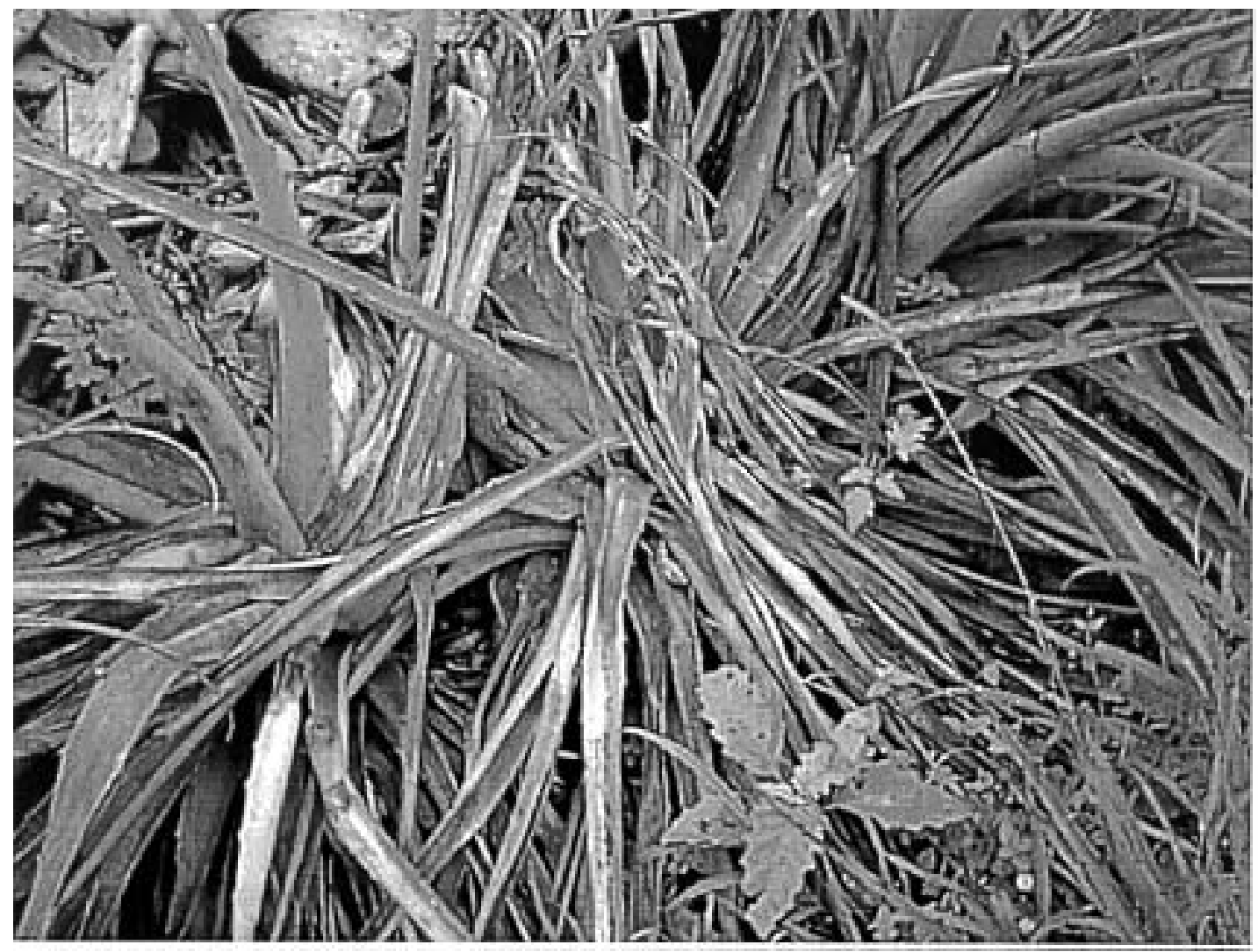

Fig. 4: Bromelia sp., chaguares. General view

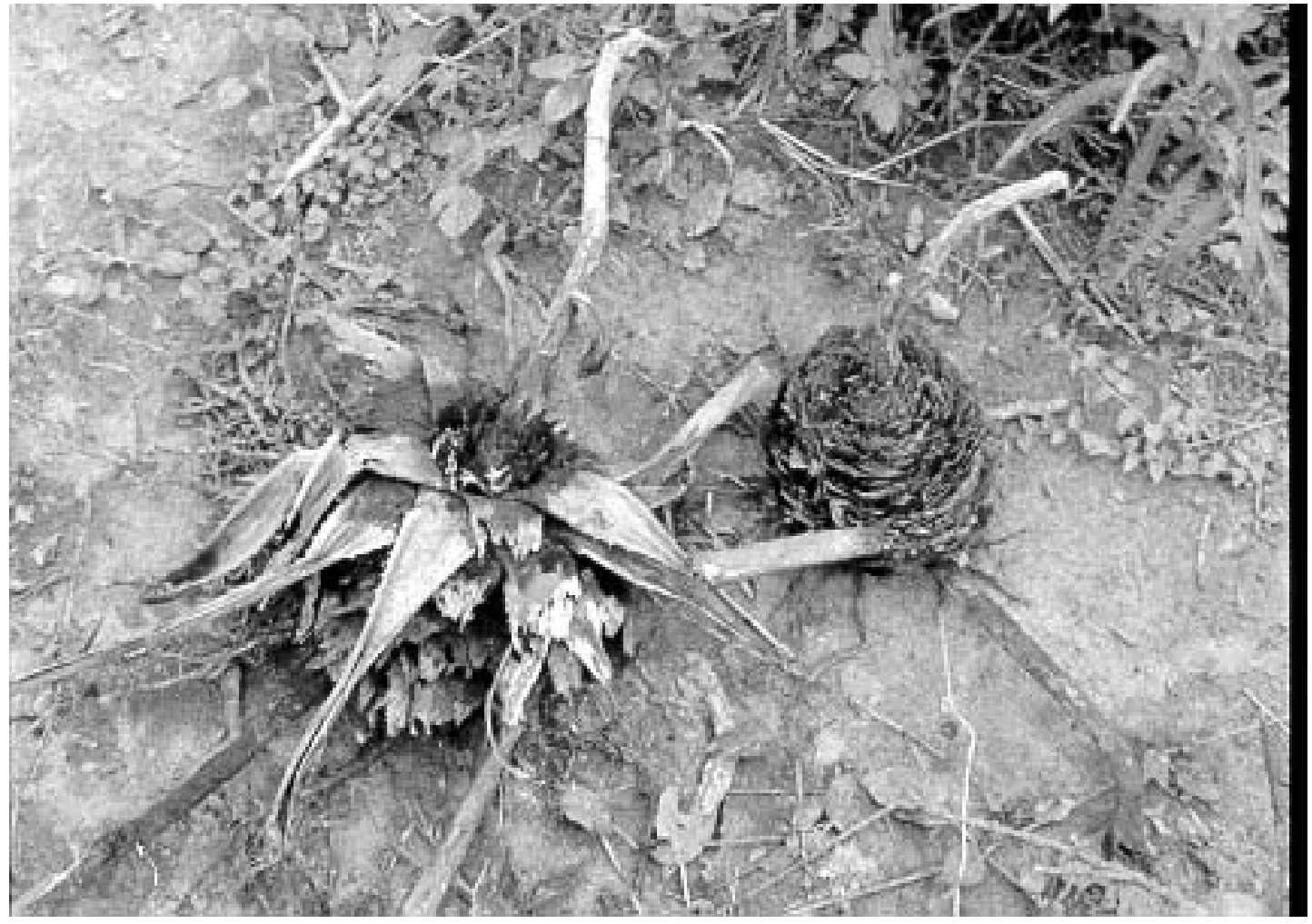

Fig. 5: Bromelia sp., chaguares. Details of central cluster of leaves 


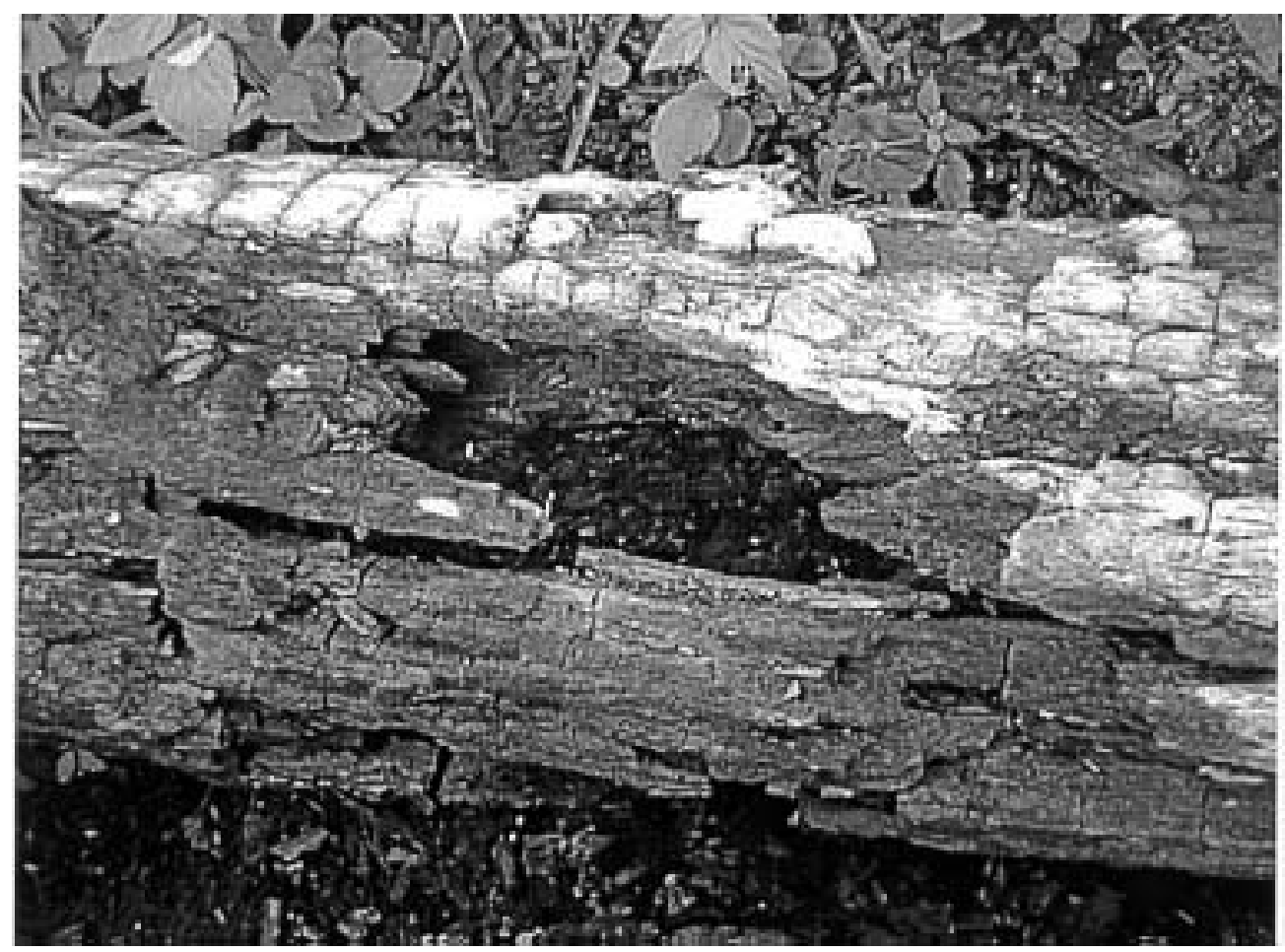

Fig. 6: log. Details of deep fissures and detached bark

The fact that the studied biotopes ranked in the same order for $T$. guasayana and the rest of the invertebrate fauna, may indicate similar arthropod microhabitat requirements.

Because T. guasayana selects biotopes regardless of their location in open (peridomestic) or forested (wild) areas (Wisnivesky-Colli et al. 1997), the general environmental condition (macrohabitat) may not be a determinant factor. On the contrary, biotope structure seems to be a key factor for $T$. guasayana colonization. According to Schofield (1979), microhabitat choice is influenced by a sense of body contact with the substrate (thigmotaxis) and triatomines prefer a rough dry surface. Our results suggest that the inner network structure of quimiles and the axilar spaces of chaguares provide the largest number of hiding and resting places.

The absence of triatomines in burrows may be partially explained by the scarcity of available shelters within these biotopes. Furthermore, several triatomine species synchronize their rhythms of activity with the light cycle (Núñez 1982, Settembrini 1984). Thus, absolute and permanent darkness in burrows might preclude triatomine colonization.

Dispersal of $T$. guasayana adults is assumed to occur at random during the reproductive season, from early spring until the beginning of summer (Wisnivesky-Colli et al. 1993a). As females spread out, they select suitable biotopes to lay eggs. The survival success of nymphs will depend on the biotope structure, which determines the number of shelters and food availability and may influence the microclimatic conditions, acting as a buffer of the environmental temperature and humidity.

In the warm season, when climatic conditions are within the appropriate range for the development of triatomines, at least half of quimiles, chaguares, and logs was infested. In the cold season, preliminary results (Wisnivesky-Colli manusc. in prep.) suggest that smallest nymphs are subject to a differential mortality among quimiles, chaguares and logs, according to the ability of these biotopes to buffer the external temperature and humidity.

Quimiles showed slight infestation rate differences between warm and cold seasons, suggesting that their microhabitat characteristics favours the persistence of $T$. guasayana colonies during adverse winter conditions.

Among all the studied biotopes, chaguares provide a large amount of blood due to domestic goats and pigs that rest near clusters of chaguares during the warm nights. This could explain the largest number of $T$. guasayana collected in chaguares in 
summer. Conversely, triatomines in quimiles feed only on small wild vertebrates, such as didelphidae, cricetidae, armadillos and reptiles (WisniveskyColli et al. 1993b).

A maximum of $14 T$. guasayana per plant was collected from the most infested biotopes in each season. The main limiting factors responsible for such low abundance may include food availability and predation. When vertebrate blood source is scarce, $T$. guasayana may occasionally ingest arthropod haemolymph, especially from Blattaria sp., ranked as the most abundant species in our collections. Such event was observed for T. sordida (ME Bar pers. commun.) under experimental and natural conditions and for T. rubrovaria in the field (Salvatella 1994). On the other hand, Ryckman and Olsen (1965) demonstrated experimentally the impact of wood rat predation on $T$. protracta. Triatomine colonies attained a carrying capacity 20 times higher when the host was restrained than when it could freely prey on the insects sharing the same box. Although potential vertebrate predators were not abundant in the study area, the high percentage of the coexisting insectivorous arthropods might produce an important triatomine mortality.

\section{ACKNOWLEDGEMENTS}

To Lic Patricia Gajate for the taxonomic determination of triatomines and to Mr Ibera and Mrs Leo Sosa for their hospitality and help during the fieldwork.

\section{REFERENCES}

Abalos JW, Wygodzinsky P 1951. Las Triatominae Argentinas (Reduviidae, Hemiptera), Monograph 2, Instituto de Medicina Regional, Tucumán, 179 pp.

Anonymous 1982. Regionalización Ecológica de la República Argentina. Centro de Investigaciones en Recursos Naturales, Instituto Nacional de Tecnología Agropecuaria, Buenos Aires, no. 173.

Cabrera AL, Willink A 1973. Biogeografía de América Latina, Monograph 13, Serie Biología OEA, Washington, $120 \mathrm{pp}$.

Fleiss JL 1981. Statistical Methods for Rates and Proportions, 2nd ed., Wiley and Sons, New York, 323 pp.

Gorla DE, Jurberg J, Catalá SS, Schofield CJ 1993. Systematics of Triatoma sordida, T. guasayana and $T$. patagonica (Hemiptera, Reduviidae). Mem Inst Oswaldo Cruz 88: 379-385.

Hutcheson K 1970. A test for comparing diversities based on the Shannon formula. J Theor Biol 29: 151-154.

Lent H, Wygodzinsky P 1979. Revision of the Triatominae (Hemiptera, Reduviidae) and their significance as vectors of Chagas disease. Bull Am Mus Hist 163: 123-520.

Magurran AE 1991. Ecological Diversity and its Measurement, Chapman \& Hall, London, 179 pp.

Noireau F, Gutiérrez T, Flores R, Breniere F, Bosseno
MF, Wisnivesky-Colli C 1999. Ecogenetics of Triatoma sordida and T. guasayana (Hemiptera, Reduviidae) in the Bolivian Chaco. Mem Inst Oswaldo Cruz 94: 451-457.

Núñez JA 1982. Food source orientation and activity in Rhodnius prolixus (Hemiptera, Reduviidae). Bull Entomol Res 72: 252-262.

Pettersen S 1976. Introducción a la Meteorología, Espasa-Calpe, Madrid, p. 398-412.

Pifano FC 1973. La dinámica epidemiológica de la enfermedad de Chagas en el Valle de los Naranjos, Estado de Carabobo, Venezuela. I Contribución al estudio de los focos naturales silvestres del Schizotripanum cruzi Chagas 1909. Arch Venez Med Trop Parasitol Med 5: 1-29.

Rabinovich JE 1985. Ecología poblacional de los triatominos. In RU Carcavallo, JE Rabinovich, RJ Tonn (eds), Factores Biológicos y Ecológicos de la Enfermedad de Chagas, Vol. 1, Servicio Nacional de Chagas, Ministerio de Salud y Acción Social, Buenos Aires, p. 121-147.

Rossell Reyes O 1984. A Comparison of the Feeding Performances of Rhodnius prolixus Stal and Rhodnius robustus Larrousse (Hemiptera: Triatominae), PhD Thesis, University of London, London, 339 pp.

Ryckman E, Olsen LE 1965. Insectivorous hosts of Triatominae. The epizootiological relationship to Trypanosoma cruzi (Kinetoplastida: Trypanosomidae) (Rodentia: Cricetidae). J Med Entomol 2: 99-104.

Salvatella R, Calegari L, Puime A, Basmadian Y, Rosa R, Guerrero J, Martínez M, Mendaro G, Briano D, Montero C, Wisnivesky-Colli C 1994. Perfil alimentario de Triatoma rubrovaria (Blanchard, 1843) (Hemiptera, Triatominae) en ámbitos peridomiciliarios de una localidad rural del Uruguay. Rev Inst Med Trop São Paulo 36: 311-320.

Schweigmann NJ 1994. Aspectos Ecológicos de una Población Santiagueña de la Comadreja Overa (Didelphis albiventris) en Relación con la Transmisión de Trypanosoma cruzi, PhD Thesis, Universidad de Buenos Aires, Buenos Aires, 184 pp.

Schweigmann NJ, Pietrokovsky SM, Bottazzi V, Conti O, Bujas MA, Wisnivesky-Colli C 1999. Estudio de la prevalencia de la infección por Trypanosoma cruzi en zarigüeyas (Didelphis albiventris) en Santiago del Estero, Argentina. Pan Am J Pub Health 78: 371-377.

Schofield CJ 1979. The behaviour of Triatominae (Hemiptera: Triatominae): a review. Bull Entomol Res 69: 363-379.

Settembrini BP 1984. Circadian rhythms of locomotion activity in Triatoma infestans (Hemiptera, Reduviidae). J Med Entomol 21: 204-212.

Wisnivesky-Colli C, Gürtler RE, Solarz ND, Schweigmann NJ, Pietrokovsky S, Alberti A, Flo J 1993a. Dispersive flight and house invasion by Triatoma guasayana and Triatoma sordida in Argentina. Mem Inst Oswaldo Cruz 88: 27-32.

Wisnivesky-Colli C, Schweigmann NJ, Pietrokovsky 
SM, Bottazzi V, Petersen R, Flo J, Conti O 1993b. Perfil alimentario de Triatoma guasayana y Triatoma sordida en el monte chaqueño de Santiago del Estero. Medicina (Buenos Aires) 53 (Supl. 1): 35-36.
Wisnivesky-Colli C, Schweigmann NJ, Pietrokovsky SM, Bottazzi V, Rabinovich JE 1997. Spatial distribution of Triatoma guasayana (Hemiptera, Reduviidae) in hardwood forest biotopes in Santiago del Estero, Argentina. J Med Entomol 34: 102-109. 